\title{
"This is really like waiting for war and this is not good" - Intertwining between pandemic experiences, and the development of professional action of healthcare professionals in critical care at the beginning of the COVID-19 pandemic in Germany: a qualitative study
}

Madlen Hörold*1, Karl Philipp Drewitz*1, Vreni Brunnthaler*2, Julia Piel ${ }^{* 1}$, Magdalena Rohr ${ }^{2}$, llona Hrudey $^{1}$, Claudia Hasenpusch ${ }^{1}$, Angela Ulrich ${ }^{1}$, Niklas Otto ${ }^{1}$, Susanne Brandstetter ${ }^{3}$, Christian Apfelbacher $^{1}$

* contributed equally

1 Otto-von-Guericke Universität Magdeburg, Institute of Social Medicine and Health Systems Research, Faculty of Medicine, Leipziger Str. 44, 39104 Magdeburg

2 University of Regensburg, Faculty of Medicine, Medical Sociology, Dr.-Gessler-Str. 17, 93053 Regensburg,

3 University of Regensburg, Faculty of Medicine, University Children's Hospital Regensburg (KUNOClinics), Steinmetzstr. 1-3, 93049 Regensburg

Correspondence to: Christian Apfelbacher, Otto von Guericke Universität Magdeburg, Institute of Social Medicine and Health Systems Research, Faculty of Medicine, Leipziger Str. 44, 39104 Magdeburg, Sachsen-Anhalt, DE, christian.apfelbacher@med.ovgu.de

\section{Abstract}

Healthcare professionals (HCPs) are facing remarkable challenges in their daily work since the outbreak of the COVID-19 pandemic. Being well prepared is crucial for dealing with such a pandemic. The aim of our study was to explore HCPs' subjective perspectives on their professional action and coping strategies in critical care during the preparation and coping phase after the outbreak of the COVID-19 pandemic in Germany.

Together with HCPs working in critical care, we collaboratively designed an interview study based on an ethnomethodological approach. We performed semi-structured qualitative interviews via telephone or video call and analysed the data based on grounded theory.

Our research interest was focused on HCPs (qualified nurses, physicians, medical students) working in critical care during the first wave of the COVID-19 pandemic in Germany between April and July 2020.

Our sample consisted of 39 HCPs (19 nurses, 17 physicians, three medical students, 18/39 female) from ten German federal states. All participants were involved in the acute care of COVID-19 infected patients in hospitals and had a mean professional experience of $14.8 \pm 10.1$ years, 15 participants held a management position (e.g. senior physician or head nurse). We recruited participants via personal contacts and snowballing.

Initial and focused coding resulted in seven categories: Creating structural measures, handling operational changes, dealing with personal protective equipment, building up knowledge and skills, managing information, perceiving peer support and experiencing emotions.

Professional action and subjectively perceived preparedness (professional and emotional) interacted with each other. Their interrelation was not static, but rather dynamic and ambiguous according to the situation. The findings of our study can be beneficial in developing guidelines, policy interventions or personnel and work practice strategies.

NOTE: This preprint reports new research that has not been certified by peer review and should not be used to guide clinical practice. 
medRxiv preprint doi: https://doi.org/10.1101/2021.01.29.21250626; this version posted March 19, 2021. The copyright holder for this

preprint (which was not certified by peer review) is the author/funder, who has granted medRxiv a license to display the preprint in

All rights reserved. No reuse allowed without permission.

\section{Introduction/ Background}

Since the outbreak of the Coronavirus Disease (COVID)-19 pandemic, health care systems across the world have been facing unprecedented challenges in continuously re-organizing (intensive) care. In the beginning, strategies for preparing for rapidly changing situations of care were accompanied by substantial uncertainty [1-3]. The German health care system has first been confronted with the novel severe acute respiratory syndrome coronavirus type 2 (SARS-CoV-2) causing COVID-19 in January 2020 [4].

The extent to which healthcare professionals (HCPs) are prepared or can be prepared for unforeseeable, dynamic changes and their impact on the care situation are decisive in determining whether comprehensive care can be provided for critically ill COVID-19 patients. Previous studies from emerging infectious diseases such as the SARS (2002-2004) or Ebola (2014-2016) outbreaks show consequences for nurses like loneliness, fatigue and sleep disorders or even posttraumatic stress disorder due to the extremely high workload and additional social isolation caused by quarantine measures [5-7]. In addition, the risk of selfinfection causes anxiety among HCPs including the fear of infecting their next-of-kin and of the increased workload due to infected and thus non-working colleagues [8-12].

Previous studies focused on psychological consequences of the pandemic. In a viewpoint, Shanafelt et al. [13] e.g. aimed to understand and address sources of anxiety among HCPs during the COVID-19 pandemic and described eight sources of anxiety, including access to appropriate personal protective equipment (PPE) and lack of access to up-to-date information and communication. Sun et al. [14] interviewed 20 nurses of the first affiliated hospital of Henan University about their psychological state and identified four topics: the presence of negative emotions at the beginning, the simultaneous or gradual appearance of positive emotions, coping mechanisms and growth under stress. In another qualitative study, Liu Yu et al. [15] described four key issues in the professional context of the respondents: Challenges and dangers, pressure due to fear of infection and high workload, strong sense of duty and a rational understanding of the epidemic. In a further study by Liu Qian et al. [16], the authors reported on three emerging issues: Responsibility for patients, challenges in the workplace and resilience in the midst of these challenges. Authors of a recent rapid review [17] including 44 studies on evidence about the psychological impact of epidemic or pandemic outbreaks on HCPs recommended that coping strategies for HCPs should be assessed and promoted as well as that sufficient PPE should be provided in order to "mitigate [...] negative psychological responses of" HCPs [17].

It is thus of essential importance to identify the strategies that HCPs are developing within their institutional environment to maintain the quality of professional care, to find out what decisions are made and which processes are initiated to re-adjust workflows and to provide appropriate care to patients under the conditions of the pandemic. To address this research gap, we set out to explore HCPs' subjective perspectives on professional action and coping strategies in acute care during the preparation and coping phase after the outbreak of the COVID-19 pandemic in Germany from March to July 2020. The main research interest of our study was to expose implicit principles that structure social practice and interaction of HCPs [18] in an exceptional situation which is characterized by a high level of change. 
medRxiv preprint doi: https://doi.org/10.1101/2021.01.29.21250626; this version posted March 19, 2021. The copyright holder for this

preprint (which was not certified by peer review) is the author/funder, who has granted medRxiv a license to display the preprint in

All rights reserved. No reuse allowed without permission.

\section{Material and Methods}

\section{Ethical considerations, data protection and privacy}

We received ethical approval for our research from the institutional review boards of the University of Magdeburg (51/20) as well as the University of Regensburg (20-1771-101) before we performed the first interview. All study activities were conducted in accordance with the declaration of Helsinki [19] and in compliance with the relevant legal regulations. Each participant received and signed a declaration of consent before we made an appointment for the respective interview. We interviewed participants individually via telephone or an appropriate video conferencing system and recorded the interview in an audio format compliant with the General Data Protection Regulation, GDPR [20]. We assured confidentiality by assigning a five-digit number for each participant. To make the results easier to read, we generated pseudonyms beyond the non-speaking numbers. These do not allow any conclusions to be drawn about the true identity of the study participants. To further fulfil GDPR compliance, we set up a trusteeship.

\section{Study design and participants}

The study is based on Garfinkel's ethnomethodological approach [18, 21] and considers everyday professional action under the circumstances of the first phase of the COVID-19 pandemic in German hospitals. In order to explore how HCPs adapt their professional actions to build up "normality", we contacted 129 hospitals or individual HCPs throughout Germany (across all 16 federal states) by different media (e-mail, telephone, professional networks, distribution of a flyer) and personal contacts via snowball sampling [22] between end of March and mid July 2020. We addressed persons from several health care professions e.g. physicians, academically qualified nursing staff and medical students in German hospitals, who were involved in the clinical acute care of COVID-19 patients requiring intensive care or monitoring. Two contacted individuals actively declined to participate in the study at the first point of contact without specific reasons, while two asked to be contacted only after the pandemic. 39 agreed to participate. All other contacts did not respond or did not get back in touch after initial communication. There was no drop-out of participants between recruitment and the actual interview. To gather rich data [23], we aimed for a heterogeneous sample both in terms of individual characteristics (e.g. work experience, gender, social and ethnic origin, educational background) and the professional environment (including the level of care provided by the hospital). Repeat interviews are carried out and will be published at a later stage.

\section{Involvement of patients/participants and public}

Patients or the public were not involved. In the beginning of the pandemic outbreak, our research team was approached by HCPs with the idea for this study. We developed the study protocol collaboratively and were supported by the initiators during the recruitment process (snowballing). All participants were informed in advance about our publication strategy, which is in line with our study protocol.

\section{Data collection}

We developed a semi-structured thematic interview topic guide (see supplementary information) based on the most relevant emerging issues and discussion points of the federal government, federal states governments, global research activities and public opinion 
medRxiv preprint doi: https://doi.org/10.1101/2021.01.29.21250626; this version posted March 19, 2021. The copyright holder for this

preprint (which was not certified by peer review) is the author/funder, who has granted medRxiv a license to display the preprint in

All rights reserved. No reuse allowed without permission.

regarding the challenges of the pandemic. This semi-structured approach supported the different interviewers in keeping the focus on the research interest and, if necessary, in responding adequately to specific events in the interview situation. Participants were initially asked about their personal experiences and feelings regarding the preparations of the institution they worked in. For this purpose, we used a narrative stimulus based on a method of Fritz Schütze [24] at the beginning of the interview: "I would like to ask you to tell us how you perceived the phase of preparation for the COVID-19 pandemic in your professional context and how you experienced it. First of all, you can take as much time as you like and speak about whatever comes to your mind." The open beginning of the interview gave the participants the opportunity to set their own relevance, to express the subjective meaning of the topic and to reflect on what they have experienced. They were encouraged beforehand to use an artefact (e.g. photographs, newspaper articles, objects, etc.) that reflected the current work situation from their perspective.

All interviewers $(n=7)$ were female with a varying degree of experience in conducting qualitative research. Four had prior experience in healthcare (one nurse, one radiographer, one psychologist, one physiotherapist). The coding and interpretation team consisted of two further male researchers and one female researcher, who also had prior experience in conducting qualitative interview studies. The entire team was composed of one professor (CA), two senior lecturers/postdoc researchers (MH, SB), three research fellows/PhDcandidates with master degree (PD, JP, MR), three junior scientists with master degree (VB, $\mathrm{IH}, \mathrm{NO})$ and two junior scientists with bachelor degree $(\mathrm{CH}, \mathrm{AU})$. Study participants belonging to the researchers' personal networks were assigned to other interviewers they did not know. Participants were informed about the professional background of the interviewers, the aim of the research and again about the relevant data protection and privacy issues. In order to contextualize the insights gained from the interviews, socio-demographic data, information on professional biography, the current situation within the current participants' workplace and various aspects of the interview situation i.e. atmosphere and interaction, were collected as data of secondary order. Some participants had a short preliminary interview as part of the scheduling process. Two interviews were conducted as pilot interviews but included in the sample.

\section{Data processing, analysis and reporting}

The audio recordings were transcribed verbatim and pseudonymised. All information allowing the identification of the interview partner was removed. We analysed the interviews in a collaborative interpretation process based on grounded theory [23, 25]. The quality and methodically controlled procedure of inductive data analysis was achieved by communicative validation within the research group through regular meetings via a video conferencing system [26]. Data was categorised into segments in order to achieve analytical accounting and build up emergent theoretical concepts [23]. During the computer-assisted (performed with either Atlas.ti or MAXQDA) data analysis, we switched between line-by-line, in-vivo, incidentto-incident and focused coding, guided by Charmaz [23]. We documented the results of the group analysis in tabular form. For collaborative interpretation, we used Confluence by Atlassian. The focused codes were collected with systematic memos accompanying the research process in a table in order to continue define conceptual categories by further coding steps [23]. We initially coded in German and then translated into English. Reporting of this study is based on the Consolidated Criteria for Reporting Qualitative Studies (COREQ) Checklist [27]. Respondent validation was not considered. 
medRxiv preprint doi: https://doi.org/10.1101/2021.01.29.21250626; this version posted March 19, 2021. The copyright holder for this preprint (which was not certified by peer review) is the author/funder, who has granted medRxiv a license to display the preprint in All rights reserved. No reuse allowed without permission.

\section{Findings}

\section{Study sample}

The sample consisted of 39 HCPs: 19 nurses, 17 physicians and three medical students from ten German federal states (see Figure 1). 46\% were female. All participants were involved in the acute care of COVID-19 infected patients in hospitals and had a mean professional experience of $14.8 \pm 10.1$ years, $42 \%$ held a management position (e.g., senior physician or head nurse). They entered COVID-19 care at different times, from mid-March to the end of May. The interviews were conducted between April 6th and July 13th and lasted about 12-66 minutes (mean $34.8 \pm 11.8$ minutes). About half (46\%) was working in maximum care hospitals (e.g., university hospitals). Further details on the characteristics of the participants are shown in Figure 1.

\begin{tabular}{|c|c|c|}
\hline Entire Sample & Physicians & Nurses \& students* \\
\hline$N=39$ (18 female) & $n=22$ (15 female) & $n=17$ (3 female) \\
\hline \multicolumn{3}{|c|}{ years of experience: $M, S D$} \\
\hline$M=14.8, S D=10,1$ & $M=16.1, S D=9.8$ & $M=13.8, S D$ \\
\hline \multicolumn{3}{|c|}{ n with management positions (\%) } \\
\hline $15(42 \%)$ & $7(37 \%)$ & $8(47 \%)$ \\
\hline \multicolumn{3}{|c|}{ type of hospital (maximum care/special care/primary care) } \\
\hline $19 / 12 / 8$ & $14 / 5 / 3$ & $5 / 7 / 5$ \\
\hline \multicolumn{3}{|c|}{ region (metropolitan area/city/small town/rural area) } \\
\hline $4 / 20 / 10 / 5$ & $2 / 15 / 3 / 2$ & $2 / 5 / 7 / 3$ \\
\hline \multicolumn{3}{|c|}{ interview duration: $M, S D$ in minutes } \\
\hline$M=34.8, S D=11.8$ & $\mathrm{M}=32.2, \mathrm{SD}=10.9$ & $M=36.8, S D=12.4$ \\
\hline
\end{tabular}

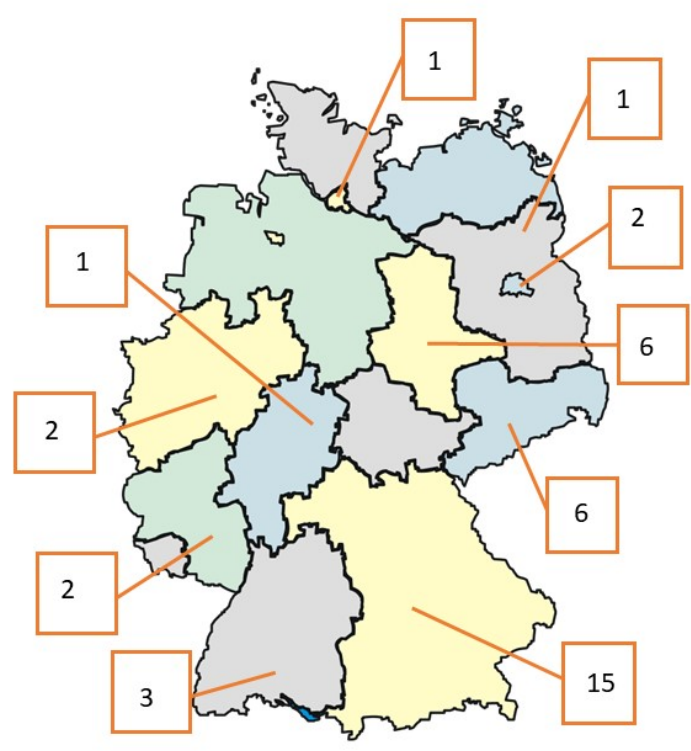

Figure 1: On the left side: Characteristics of the study sample; on the right side: Regional distribution of participants for each German federal state (Bundesland)

*) 3 medical students, who had nursing experience before and volunteered on the respective ICU during the pandemic

\section{Categories and concepts}

A focus of questioning the data was on thematic redundancies the participants made, and what theories, motives, evaluations, justifications and further explanations as well as symbolic markers were referred to frame described actions. In this context, we already became aware of the significance of metaphorical terms that invoke martial or catastrophic scenarios during initial coding.

Initial and focused coding resulted in seven inductively created categories each with subordinate concepts on experiences and the development of professional actions and coping strategies of HCPs in acute care:

- Creating structural measures,

- Handling operational changes,

- Dealing with personal protective equipment,

- Building up knowledge and skills, 
medRxiv preprint doi: https://doi.org/10.1101/2021.01.29.21250626; this version posted March 19, 2021. The copyright holder for this

preprint (which was not certified by peer review) is the author/funder, who has granted medRxiv a license to display the preprint in perpetuity.

All rights reserved. No reuse allowed without permission.

- Managing information,

- Perceiving peer support and

- Experiencing emotions.

The first concept within the category "Creating structural measures" was searching and finding solutions. In the hospitals, multidisciplinary crisis teams or task forces were set up as an extension of the hospital management, which centrally determined the measures for the respective facilities (based on legal requirements). The task forces met daily or weekly. Their decisions had a strong impact on the structures and operational processes. The second concept was building up COVID-19 units. The participants reported that different organizational measures have been undertaken to create capacities for a possibly large number of COVID-19 infected persons. Thus, intensive care units (ICU) were extended (partly also by structural measures), regular wards were closed, merged, medically rededicated or equipped with other medical technology. As a third concept, we elaborated managing human resources. In order to increase personnel capacities, employees were reallocated, qualified or recruited (with and without previous medical/nursing experience). In addition, the support of volunteers was requested. Frontline workers received support through, for example, the offer for talks with chaplains or a crisis intervention team, free drinks and food, massages or even staff supervising the correct donning and doffing.

The second category "Handling operational changes" consisted of three concepts: Implementing new workflows, balancing voluntary work and duty, and task sharing and changing responsibilities. The participants reported about implementing new workflows in their units through operational changes. For example, access to the departments was restricted or zoned within the COVID-19 units (similar to a traffic light system). Routines got lost, workflows were adapted, and support services offered. Locking in and out of patients' rooms was reduced to a minimum to protect against infection. Accordingly, all activities in the patients' room and the required equipment had to be well prepared. The balancing voluntary work and duty concept was an expression of an ongoing negotiation process of the management. On the one hand, employees (physicians and nurses) who volunteered to care for COVID-19 patients staffed units. On the other hand, employees were confronted with the care of COVID-19 patients through the reassignment of areas. In particular, staff with personal risk profiles for severe progression of COVID-19 if infected were looking for ways out of this service commitment, sometimes solutions were found. The concepts task sharing and changing responsibilities described changes in direct patient care. The participants talked about the support of colleagues without ICU skills, auxiliaries and service staff and the associated assignment/allocation of tasks, as well as changes in rostering (floater, digitalization). Individual physicians and nurses described a change of roles in the patient room: Some doctors took over nursing tasks and vice versa. Some nurses reported that ward rounds were carried out without doctors seeing the patients.

The third category "Dealing with personal protective equipment" (PPE) consisted of three concepts relating to organisational, operational and individual aspects. We called the first concept rationing. The participants described a deficiency and rationing of PPE. Due to theft, the equipment had to be stored in locked rooms and was only handed out personally to each employee per shift. This also involved the implementation of new procedures. The second concept was opening up creative procurement channels. Participants reported many different efforts by hospitals; such as purchasing in the hardware store, using the private neighbour's 
medRxiv preprint doi: https://doi.org/10.1101/2021.01.29.21250626; this version posted March 19, 2021. The copyright holder for this

preprint (which was not certified by peer review) is the author/funder, who has granted medRxiv a license to display the preprint in

All rights reserved. No reuse allowed without permission.

3D printer. High prices were paid to medical device companies to provide protective equipment to employees. With regard to lowering quality standards as the third concept, participants described how they suddenly had to use respirators and protective gowns more than once, despite previous hygiene rules.

The fourth category "Building up knowledge and skills", consisted of the three concepts donning and doffing, training ICU skills and being instructed in new devices. Participants defined donning and doffing as an important training measure in infection control. Teaching material such as video sequences was provided, and techniques were practiced under supervision. In addition, participants told of (short) training courses to build up ICU skills. Employees without or with little ICU experience were prepared for a possible assignment. There were differences in training contents and scope. However, the focus was mainly on equipment, ventilation and monitoring. In order to ensure the care of a potentially large number of critically ill patients, all available equipment, especially (home-) respiration, injection pumps and dialysis machines, was (re)activated and partly newly purchased. Accordingly, employees were instructed in how to work with these devices.

The fifth category "Managing information" consisted of four concepts: Being confronted with flood of information with limited validity, exploring new digital world, talking and listening and being confronted with "Corona" everywhere. Within the first concept, the participants described their efforts in collecting information and difficulties in managing its large amount (by handout, e-mail and telephone). Within a very short time, management revised work instructions and process descriptions. The second concept was called exploring new digital world. The participants talked about an increasing use of the intranet, about video messages and instructional videos up to the development of apps for rostering. Especially supervisors described the importance of talking and listening (third concept) during this time. They mentioned the importance of listening to employees' needs and concerns, answering their questions and explaining current measures. The fourth concept was called being confronted with "Corona" everywhere. The participants described the COVID-19 pandemic as an omnipresent phenomenon that accompanied their everyday communication both in the professional and the private environment.

The sixth category covered the field of "Perceiving peer support". In dealing with professional changes participants reported perceiving peer support. This category consisted of two concepts: Feeling supported by family and friends and feeling collegiality and teamwork. The participants mentioned family and friends as an important resource. They listened, were simply there or took care of the children. Furthermore, with regard to the second concept feeling collegiality and teamwork, the participants talked about experiencing support from colleagues and about working in a (multi-professional) team. They described changes in teams through new colleagues and structures. The team spirit seemed to have an impact on the experience of support. Successful teamwork was perceived as a great value.

The seventh category, "Experiencing emotions", described the different and sometimes dynamic emotional world of the participants, which we represented in the concepts of having negative emotions, being proud and satisfied and being "Corona heroes". The participants in particular, expressed stress during work, although often fewer patients were treated on ICU than before the pandemic. They also spoke about worries, fears, frustration, anger and doubts, isolation (concept of having negative emotions). Worries and fears were often related 
medRxiv preprint doi: https://doi.org/10.1101/2021.01.29.21250626; this version posted March 19, 2021. The copyright holder for this

preprint (which was not certified by peer review) is the author/funder, who has granted medRxiv a license to display the preprint in All rights reserved. No reuse allowed without permission.

to the lack of PPE and information, to the perceived uncertainty about the course of the pandemic, the experience of lack of structure and the assessment of one's own resilience and the possibility of family support. The participants mentioned frustration and anger, especially in relation to the lack/rationing of PPE and staff shortages. Some participants felt that superiors did not sufficiently inform about strategic decisions nor supported them in their operational problems. Nurses and physicians in a management position expressed doubts about being capable to develop good and sustainable solutions and lead the hospital through the pandemic. All these negative feelings were also related to the experience of psychological burden. In contrast, participants reported also being proud and satisfied (second concept) of their own work, the possibility to help. They gained self-affirmation through their commitment. This seemed to be the driving force behind the motivation to work. We particularly identified motivated participants as "Corona Heroes". They described the COVID19 pandemic as eventisation and possibility of (public) attention leading to an increase in motivation and engagement. The "Experiencing emotions" category with its concepts overlapped with most of the other categories: Emotions were influenced by an individual's behaviour as well as by the behaviour of others. Table 1 presents the inductive categories with respective concepts in an aggregated overview. Figure 2 contextualises the categories and relates them to each other. It is part of the coding and interpretation process to elaborate the central phenomenon and to transfer the structure of the emerged categories into a theory.

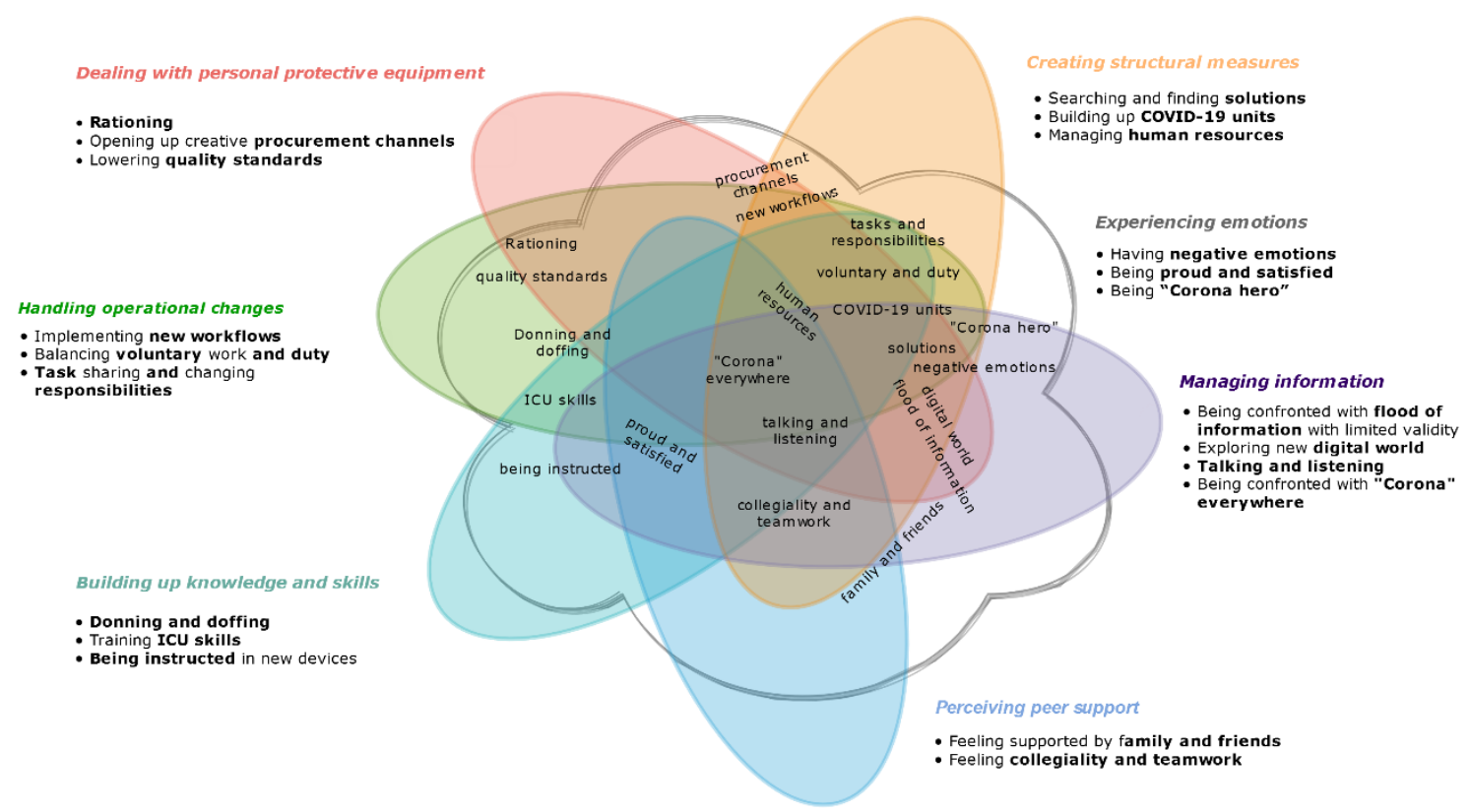

Figure 2 Situational map of intertwining of different phenomena/processes discovered during interpretation 
Table 1: Aggregated overview of inductive categories with respective concepts and exemplary quotes

\begin{tabular}{|c|c|}
\hline Categories and concepts & Exemplary quotes \\
\hline \multicolumn{2}{|c|}{ Creating structural measures } \\
\hline \multirow{2}{*}{$\begin{array}{l}\text { Searching and finding } \\
\text { solutions }\end{array}$} & $\begin{array}{l}\text { "We found out that our number of intensive care beds won't be enough, [...], also the anaesthesia equipment won't be enough, so in the end I [tried] to organize equipment } \\
\text { from the homecare area that is licensed for invasive ventilation therapy [in the hospital]." - Elisabeth Huber, physician }\end{array}$ \\
\hline & "It was totally chaotic, I think. So there was no structure behind it, I think." - Christian Trüb, nurse \\
\hline Building up COVID-19 units & $\begin{array}{l}\text { "We then selected two stations in the house. A monitoring station and a cardiology monitoring station. Then we upgraded them with at least some inferior home ventilators } \\
\text { and respirators that were still available." - Karl Mohn, physician }\end{array}$ \\
\hline Managing human resources & $\begin{array}{l}\text { "Another important point was the training and recruitment of new employees or even the redistribution of employees from other departments [...], which were not familiar } \\
\text { with the internal medicine. Surgeons worked with them, neurologists worked with them and the same applied to nursing care. In the end, the staff had to be trained both } \\
\text { in the normal ward and in the intensive care unit, as well as the staff who worked in the intensive care unit." - Elisabeth Huber, physician }\end{array}$ \\
\hline \multicolumn{2}{|c|}{ Handling operational changes } \\
\hline \multirow{2}{*}{$\begin{array}{l}\text { Implementing new } \\
\text { workflows }\end{array}$} & $\begin{array}{l}\text { "It was more problematic in this chaos (laughing), where people were divided into new intensive units, where they had to see for themselves, [...] there are students as } \\
\text { assistants, new stand-by men, but also people who want to be trained, both medical and nursing, that there suddenly was a huge amount of people on the intensive units } \\
\text { and that it was not easy to act." - Elisabeth Huber, physician }\end{array}$ \\
\hline & $\begin{array}{l}\text { "[...] we started by sticking red tape on the floor of the units, what is the so-called clean area and what is unclean and nobody wearing personal protective equipment may } \\
\text { enter the clean area, not even putting his hand there." - Martin Kurtz, physician }\end{array}$ \\
\hline $\begin{array}{l}\text { Balancing voluntary work } \\
\text { and duty }\end{array}$ & $\begin{array}{l}\text { "[...] to care for COVID patients they drew straws who is now caring for COVID patients and these were highly dramatic pictures, so that our nursing management actually } \\
\text { had to send people away because they were not able to organize themselves, i.e. to arrange themselves." - Thomas Steiner, physician }\end{array}$ \\
\hline \multirow[t]{2}{*}{$\begin{array}{l}\text { Task sharing and changing } \\
\text { responsibilities }\end{array}$} & $\begin{array}{l}\text { "In our case, a [...] team consisted of four people, namely a team lead [...], which was an intensive care nurse. The second companion was a physician, who is experienced } \\
\text { in intensive care, but I deliberately did not give him the lead; instead, the lead was with the intensive care nurse. Then a physician who can intubate and do critical care. } \\
\text { The third hand was still a nurse, [...], but not necessarily [...] a specialist nurse intensive care. The fourth hand was a [....] medical student in his final year. So we consistently } \\
\text { planned these four [...] then we modularized that." - Martin Kurtz, physician }\end{array}$ \\
\hline & "But nurses are just like that, they just do it. And the physicians try that they avoid going into the room [...]." - Tina Hirsch, nurse \\
\hline \multicolumn{2}{|c|}{ Dealing with personal protective equipment } \\
\hline Rationing & $\begin{array}{l}\text { "We are partly short of consumables, so we knew that if we didn't get anything today, we'd be out in two days. That's how tight we were. Both of medicines partly, and } \\
\text { protective gowns, as well as protective masks." - Elisabeth Huber, physician }\end{array}$ \\
\hline $\begin{array}{l}\text { Opening up creative } \\
\text { procurement channels }\end{array}$ & "[...] our respiratory therapists neighbour had a 3D printer that printed visors for us" - Thomas Steiner, physician \\
\hline Lowering quality standards & $\begin{array}{l}\text { "Yes, because uh when I am on the patient, it was the original one, anyway, and leaving the room I also change the protective gown. Now suddenly I have to wear this } \\
\text { protective gown the whole shift. When I leave the room I put it on the hook and when I go back in I have to use it again." - Svenja Fischer, nurse }\end{array}$ \\
\hline \multicolumn{2}{|c|}{ Building up knowledge and skills } \\
\hline \multirow[b]{2}{*}{ Donning and doffing } & $\begin{array}{l}\text { "I say the FFP2, FFP3 masks, a everybody is also trained in handling them [...] we also did clean practice, [...] always dressed in pairs, that means, I also practiced that in the } \\
\text { intensive care unit with the nurses so that one always looks that one dresses and undresses properly, you need help." - Stefan Meihofer, physician }\end{array}$ \\
\hline & $\begin{array}{l}\text { "I [...] and also train hygiene concepts. How do I first safely get out of the protective equipment without contaminating myself and second how do I put it off properly and } \\
\text { put it back on right without contaminating myself (breathing). That was a huge hygiene training." - Elisabeth Huber, physician }\end{array}$ \\
\hline
\end{tabular}




\section{Categories and concepts}

Training ICU skills

Being instructed in new devices

\section{Managing information}

Flood of information with limited validity

\section{Exploring new digital world}

Talking and listening

Being confronted with Corona everywhere

\section{Perceiving peer support}

Feeling supported by family and friends

Feeling collegiality and teamwork

\section{Experiencing emotions}

\begin{tabular}{|c|c|}
\hline \multirow{3}{*}{ Having negative emotions } & $\begin{array}{l}\text { "[...] that's really like waiting for war and that's not good. Because one always had the feeling, "When will it finally start?" and "Are we well prepared?" - Martin Kurtz, } \\
\text { physician }\end{array}$ \\
\hline & $\begin{array}{l}\text { "Another problem was the psychological effect of the employees. One treats the disease; one knew it was highly contagious [...] when we treated the first patient, it was } \\
\text { emotionally difficult for me. Simply out of fear of infecting me." - Elisabeth Huber, physician }\end{array}$ \\
\hline & $\begin{array}{l}\text { "We are a hotspot, the war has broken out here. I can't express it any other way, it was insane. Everything is now running in a more orderly fashion. It's not as bad as it } \\
\text { was in the beginning. But I say the first six weeks were hell" - Elisabeth Huber, physician }\end{array}$ \\
\hline Being proud and satisfied & "We also have and I am very, very, very proud of this, not a single infection within the nursing team and no transmission to other patients." - Thomas Steiner, physician \\
\hline \multirow[t]{2}{*}{ Being “Corona hero" } & $\begin{array}{l}\text { "So, yes, for me that also gives the professional work something special. And it is also a certain motivation. Also, of course, when there is media interest in a very concrete } \\
\text { way, television was more often with us at the ward, interviews ... You already feel a kind of appreciation." - Herbert Meister, nurse }\end{array}$ \\
\hline & "I volunteered for this because ... it's also an interesting topic ... and I also find it interesting to see the intensive care units in France." - Christian Trüb, nurse \\
\hline
\end{tabular}

\section{Exemplary quotes}

"Our nursing school was stopped, [...] we had timetables really over weeks, everything around the topic oxygen, artificial respiration, equipment briefing, equipment briefing in smallest devices, so what one needs intensive-medically also. Ventilation for beginners. We offered prone position training and so on. There was a timetable that went on for weeks, where nurses and physicians who had nothing to do with intensive care could go to." - Elisabeth Huber, physician

"So we realized okay, our number of intensive care beds won't be enough, [...], even with anaesthesia equipment it won't be enough, so in the end I'm organizing from the homecare area devices that have an approval for invasive ventilation therapy." - Elisabeth Huber, physician

"Of course, people have also thought about using devices in an emergency for things that might not necessarily be used otherwise because they are older or-. Transport monitors, for example, for normal ventilation, if that's what is needed." - Karsten Steffen, physician

"Then of course it is very difficult, you get 50 mails a day [...]." - Sophie Schünemann, nurse

"Information in written form, that was a bit much and that was also very difficult because it changed every day. [...] additionally with so many notes and novelties every day." - Kerstin Müller, nurse

"[..] I made a fool of myself and shot a video for the whole staff, which was on the intranet and then always ran." - Martin Kurtz, physician "In principle, we tried to talk to people every day and every hour and every minute, so that no one would have the feeling that they were left alone with the problem. But it could not be solved immediately." - Karsten Steffen, physician "Work Corona, News Corona, Radio Corona" - Rebecca Amman, physician

"That was it-, you really spent eight hours here in the hospital and could not hear the word Corona after eight hours, I say so jokingly. [...] I did not turn on a television or radio, I said, "I can't hear it anymore." - Hanna Läufert, nurse

Ihad great support at home. I do not have the problem of having to justify myself at hor "So when I now refer to the hospital it is actually always my work colleagues who give me the strength and the support I say." - Kristin Baumann, nurse

"The fact that I had great people on my side. To see, for example, that our head of intensive care, a woman and a man, were so cool in their work, but also that all my senior physicians were ready to help, [...]. Luckily, it also worked out really well that there was a real team spirit and that you had the feeling that "People, that's what we studied for, that's what we were trained for" and that you were able to unite everyone behind this flag." - Martin Kurtz, physician

"[...] that's really like waiting for war and that's not good. Because one always had the feeling, "When will it finally start?" and "Are we well prepared?" - Martin Kurtz, "Another problem was the psychological effect of the employees. One treats the disease; one knew it was highly contagious [...] when we treated the first patient, it was "We are a hotspot, the war has broken out here. I can't express it any other way, it was insane. Everything is now running in a more orderly fashion. It's not as bad as it

"I volunteered for this because ... it's also an interesting topic ... and I also find it interesting to see the intensive care units in France." - Christian Trüb, nurse 
medRxiv preprint doi: https://doi.org/10.1101/2021.01.29.21250626; this version posted March 19, 2021. The copyright holder for this

preprint (which was not certified by peer review) is the author/funder, who has granted medRxiv a license to display the preprint in

All rights reserved. No reuse allowed without permission.

The identified categories were closely interwoven; their interrelation was not static, but rather dynamic according to the situation. We were able to map trajectories between the categories in a multidimensional framework (see Figure 2). This first heuristic modelling of the categories gives a preview of a theoretical model that will be continued [23]. It represents the interpretation of the perspective of the respondents and summarizes the processes in the field. Based on the multidimensional arrangement of the categories and concepts, we kaleidoscopically arranged intersections, which suggest social interactions on various levels and provide indications of the emergence of "agency" from the perspective of the HCPs under the dynamic situation.

In the following we will explain the intertwining using examples. At first, the concept of having negative emotions and the associated stressful experiences. The participants talked about nerve-racking situations in connection with direct patient care, especially through PPE and adaptation to new operational measures. Furthermore, stressful feelings were discussed in relation with managing information, and the perceived lack of leadership ( $\rightarrow$ Creating structural measures).

(The concept-) Lowering quality standards (in the category dealing with PPE) resulted in new workflows and was thus part of the operational measures in hospitals. Participants reported new, lower quality standards regarding PPE, especially through rationing. This also triggered (negative) emotions among the participants. They expressed worries, fears and anger.

The concept human resources in the Creating structural measures category has intertwining with three other categories. The participants reported that employees were redistributed within the hospital, which created new workflows (handling operational changes). The management also recruited staff (with and without previous medical/nursing experience) and initiated training for existing and new employees with the necessary knowledge and skills to treat COVID-19 patients. In this context, there are interactions with emotions as well. Participants declared concerns about a perceived lack of staff and the loss of routines.

The concept of collegiality and team belongs to the Perceiving peer Support category. This concept also has intertwining to other categories/concepts. As a consequence of operational measures, changes in team structures and cooperation occurred. The teams provided support in managing information and dealing with PPE, through the possibility of talking and listening and in handling new workflows. The participants also reported on effects on their emotions: On the one hand, teamwork was associated with positive emotions. On the other hand, dysfunctional teams led to negative emotions among participants. 
medRxiv preprint doi: https://doi.org/10.1101/2021.01.29.21250626; this version posted March 19, 2021. The copyright holder for this

preprint (which was not certified by peer review) is the author/funder, who has granted medRxiv a license to display the preprint in

All rights reserved. No reuse allowed without permission.

\section{Discussion}

We examined how HCPs constructed the frame of professional action during the preparation and coping phase for the care of COVID-19 patients in Germany. The focus was on investigating HCPs' specific experiences and associated actions. Seven main categories were identified from participants' accounts: Creating structural measures, handling operational changes, dealing with personal protective equipment, building up knowledge and skills, managing information, perceiving peer support and experiencing emotions.

We found that the identified categories and concepts in our data were highly dynamic, as well as the resulting cause-and-effect forces, both contributing to changes in professional actions. Adopting a systemic perspective, we showed that processes in critical care always need to be considered multi-dimensional and that changes on one level always have an impact on other areas. Respondents used the interview as an opportunity for personal voice. Part of the sample complained about inadequate working conditions, which were intensified with the pandemic. Understanding the experiences gained by HCPs can lead to recommendations for action.

During a time of intense workload for people working in acute care we succeeded in recruiting 39 HCPs, from different regions in Germany, from high and low volume hospitals, before, during or after the care for the first wave of COVID-19 patients. Both nurses and physicians were included, reflecting everyday work in hospitals, but the sample consisted of mainly white German-speaking persons. Increasingly people with a migrant background are working in the healthcare sector and their perspectives may be different. Further, our sampling strategy was likely to identify participants who are highly motivated or particularly concerned about the pandemic. Data collection and analysis was organised in an ongoing circle allowing for maximum openness and for adjusting the design in the course of data collection and data analysis [23]. As interviews were conducted using telephone or video conferencing systems, it was sometimes difficult to build a trusting relationship with participants, since non-verbal cues could not be obtained. The subsequent translation of the research results and quotations carries the risk of losing or alienating the meaning [28]. Gender-specific dynamics in the interviews cannot be excluded, since only women conducted all interviews [29]. The varying degree of experience in conducting qualitative research or prior work experience in healthcare (four/seven interviewers) might have influenced the data collection and analysis, too.

Some of our study findings relate to the results of other studies conducted in the context of the COVID-19 pandemic. The key category - experiencing emotions - showed how the pandemic and the associated work-related processes/phenomena triggered emotions in HCPs, or how emotions influenced the experience of work-related processes/phenomena. Experiencing emotions interacted with all other categories; their interrelation was not static, but rather dynamic and ambiguous according to the situation. This is in line with Sun et al. [14], who also indicated that positive emotions occurred simultaneously with negative emotions. They discovered the phenomenon "growth under pressure", which included increased affection and gratefulness, development of professional responsibility, and selfreflection [14].

Our findings regarding PPE and (psychosocial) support are consistent with previous published studies [14, 17, 30, 31]. Vindrola-Padros et al. [32] reported about limited PPE and lack of routine testing and the relation to anxiety and distress in HCPs. When PPE was available, incorrect size and overheating made daily work difficult. Lack of training for redeployed staff and the failure to consider the skills of redeployed staff for new areas were identified as serious challenges. Positive aspects of daily work reported by HCPs included solidarity between colleagues, the establishment of support structures and feeling valued by society. 
medRxiv preprint doi: https://doi.org/10.1101/2021.01.29.21250626; this version posted March 19, 2021. The copyright holder for this preprint (which was not certified by peer review) is the author/funder, who has granted medRxiv a license to display the preprint in All rights reserved. No reuse allowed without permission.

Authors of a recent rapid review [17] recommended that coping strategies for HCPs should be assessed and promoted as well as that sufficient PPE should be provided in order to "mitigate [...] negative psychological responses of" HCPs [17]. Adjustments of hospital infrastructure to COVID-19 (e.g. sufficient staff, keeping teams and working schedules stable) could support HCPs [31].

Preparing HCPs and encouraging (organisational) coping strategies seems to be very important in order to prevent anxiety, uncertainty, conflicts within working teams and long-term negative health consequences. Experiences of HCPs during the first SARS outbreak have shown the relevance of professional as well as emotional preparedness of HCPs with regard to coping strategies in a new care situation [14]. Employers of HCPs should be/become aware of the dynamics and complexity of the system and support coping and the development of professional actions through appropriate measures, e.g. regular and intensive training [16]. Conditions of insufficient human/material resources or lacking life-support measures, leading to end-of-life decisions [33-35] should be avoided. Our study highlights the importance of complexity of critical care and deriving situation-specific measures. It also demonstrates that positive emotions among employees are motivating; challenging circumstances can provide precious experiences and important insights - especially regarding teamwork, workflow and responsibilities. Therefore, it would be beneficial to consider the described experiences of the HCPs as learning processes and to feed them back into practice. Furthermore, our results can be beneficial in developing guidelines regarding infrastructure, policy interventions or personnel and work practice strategies.

By now, hospitals in Germany are challenged by the second wave of COVID-19 patients. We do not know whether experiences from the first wave as expressed by our study participants were used for improving the working conditions and quality of care and how HCPs evaluated their own and their hospitals actions during the pandemic retrospectively. Future studies which adopt a longitudinal perspective are necessary. 
medRxiv preprint doi: https://doi.org/10.1101/2021.01.29.21250626; this version posted March 19, 2021. The copyright holder for this preprint (which was not certified by peer review) is the author/funder, who has granted medRxiv a license to display the preprint in All rights reserved. No reuse allowed without permission.

\section{Declarations}

CA is principal investigator of a study which develops and pilot tests an intensive care followup clinic. Further, he is spokesperson of the working group "Intensive care and critical illness" of the German Network Health Services Research, and member of the Scientific Advisory Board of the Eric project. All other authors declare no conflict of interest. All authors read the final version of the manuscript and approved its submission for publication. The corresponding author attests that all listed authors meet authorship criteria and that no others meeting the criteria have been omitted.

\section{Transparency declaration}

The lead authors (the manuscript's guarantors) affirm that the manuscript is an honest, accurate, and transparent account of the study being reported. No important aspects of the study have been omitted. Discrepancies from the study as have been explained.

\section{Dissemination declaration}

Study participants will receive an overview of preliminary results after the follow-up interview in the form of a conference abstract. Further, the submission of this article will be followed by the dissemination of the study findings in plain language to the relevant professional associations.

\section{Author contributions (CRediT - Contributor Roles Taxonomy):}

Madlen Hörold (formal analysis, investigation, methodology, validation, visualisation, writing/original draft, writing/review\&editing), Karl Philipp Drewitz (conceptualisation, data curation, formal analysis, methodology, project administration, supervision, validation, visualisation, writing/original draft, writing/review\&editing), Vreni Brunnthaler (data curation, formal analysis, investigation, methodology, project administration, validation, visualisation, writing/original draft, writing/review\&editing), Julia Piel (formal analysis, investigation, methodology, validation, visualisation, writing/original draft, writing/review\&editing), Magdalena Rohr (conceptualisation, data curation, formal analysis, methodology, project administration, validation, visualisation, writing/review\&editing), Ilona Hrudey (formal analysis, investigation, validation, writing/review\&editing), Claudia Hasenpusch (formal analysis, investigation, validation, writing/review\&editing), Angela Ulrich (formal analysis, investigation, validation, writing/review\&editing), Niklas Otto (formal analysis, investigation, validation, writing/review\&editing), Susanne Brandstetter (formal analysis, methodology, supervision, writing/review\&editing), Christian Apfelbacher (conceptualisation, funding acquisition, methodology, project administration, supervision, writing/review\&editing)

\section{Funding statement}

Intramural funding was used to support the study.

\section{Data sharing}

Data can be obtained from the corresponding author upon reasonable request. 
medRxiv preprint doi: https://doi.org/10.1101/2021.01.29.21250626; this version posted March 19, 2021. The copyright holder for this preprint (which was not certified by peer review) is the author/funder, who has granted medRxiv a license to display the preprint in All rights reserved. No reuse allowed without permission.

\section{Acknowledgements}

We are indebted to Maximilian Malfertheiner for initial discussions which led to the planning of the study, and to Julika Loss for supporting the study through additional intramural funding. Further, we are grateful to Stefanie March for advice in the planning of the study, to Heike Hupach for supporting the recruitment of potential study participants and to Christoph Damm for his input in the interpretation phase of the study. We thank Johannes Bernarding and Markus Plaumann for their advice and establishment of a trusteeship as part of our study. We would like to thank all the interview participants for their time and their openness to talk to us. 
medRxiv preprint doi: https://doi.org/10.1101/2021.01.29.21250626; this version posted March 19, 2021. The copyright holder for this

preprint (which was not certified by peer review) is the author/funder, who has granted medRxiv a license to display the preprint in perpetuity.

All rights reserved. No reuse allowed without permission.

\section{References}

1 Bambi S, lozzo P, Rasero L, et al. COVID-19 in Critical Care Units: Rethinking the Humanization of Nursing Care. Dimens Crit Care Nurs 2020;39(5):239-41.

2 Phua J, Weng L, Ling L, et al. Intensive care management of coronavirus disease 2019 (COVID-19): challenges and recommendations. The Lancet Respiratory Medicine 2020;8(5):506-17.

3 Goh KJ, Wong J, Tien J-CC, et al. Preparing your intensive care unit for the COVID19 pandemic: practical considerations and strategies. Crit Care 2020;24(1):215.

4 Böhmer MM, Buchholz U, Corman VM, et al. Investigation of a COVID-19 outbreak in Germany resulting from a single travel-associated primary case: a case series. The Lancet Infectious Diseases 2020;20(8):920-28.

5 Liu C, Wang H, Zhou L, et al. Sources and symptoms of stress among nurses in the first Chinese anti-Ebola medical team during the Sierra Leone aid mission: A qualitative study. International Journal of Nursing Sciences 201 9;6(2):187-91.

6 Chung BPM, Wong TKS, Suen ESB, et al. SARS: caring for patients in Hong Kong. J Clin Nurs 2005;14(4):510-17.

7 Carmassi C, Foghi C, Dell'Oste V, et al. PTSD symptoms in healthcare workers facing the three coronavirus outbreaks: What can we expect after the COVID-19 pandemic. Psychiatry Res 2020;292:113312.

8 Maunder, R., Hunter, J., Vincent, L., Bennett, J., Peladeau, N., Leszcz, M., Mazzulli, T. The immediate psychological and occupational impact of the 2003 SARS outbreak in a teaching hospital. CMAJ Open 2003;168(10):1245-51.

9 Chan-Yeung M. Severe acute respiratory syndrome (SARS) and healthcare workers. International journal of occupational and environmental health 2004;10(4):421-27.

10 Buselli R, Corsi M, Baldanzi S, et al. Professional Quality of Life and Mental Health Outcomes among Health Care Workers Exposed to Sars-Cov-2 (Covid19). Int J Environ Res Public Health 2020;17(17).

11 Rajkumar RP. COVID-19 and mental health: A review of the existing literature. Asian J Psychiatr 2020;52:102066.

12 Liu C-Y, Yang Y-Z, Zhang X-M, et al. The prevalence and influencing factors in anxiety in medical workers fighting COVID-19 in China: a cross-sectional survey. Epidemiol Infect 2020;148:e98.

13 Shanafelt T, Ripp J, Trockel M. Understanding and Addressing Sources of Anxiety Among Health Care Professionals During the COVID-19 Pandemic. JAMA 2020;323(21):2133-34.

14 Sun N, Wei L, Shi S, et al. A qualitative study on the psychological experience of caregivers of COVID-19 patients. Am J Infect Control 2020;48(6):592-98.

15 Liu Y-E, Zhai Z-C, Han Y-H, et al. Experiences of front-line nurses combating coronavirus disease-2019 in China: A qualitative analysis. Public Health Nurs 2020.

16 Liu Q, Luo D, Haase JE, et al. The experiences of health-care providers during the COVID-19 crisis in China: a qualitative study. The Lancet Global Health 2020;8(6):e790-e798.

17 Preti E, Di Mattei V, Perego G, et al. The Psychological Impact of Epidemic and Pandemic Outbreaks on Healthcare Workers: Rapid Review of the Evidence. Curr Psychiatry Rep 2020;22(8):43.

18 Abels H. Identität, 3rd edn. Wiesbaden: Springer VS 2017.

19 World Medical Association. Declaration of Helsinki: ethical principles for medical research involving human subjects. JAMA 2013;310(20):2191-94. 
medRxiv preprint doi: https://doi.org/10.1101/2021.01.29.21250626; this version posted March 19, 2021. The copyright holder for this

preprint (which was not certified by peer review) is the author/funder, who has granted medRxiv a license to display the preprint in

All rights reserved. No reuse allowed without permission.

20 European Union. Regulation (EU) 2016/679 of the European Parliament and of the Council of 27 April 2016 on the protection of natural persons with regard to the processing of personal data and on the free movement of such data, and repealing Directive 95/46/EC (General Data Protection Regulation): GDPR 2018.

21 Pillay R. Ethnomethodology. In: Liamputtong P, ed. Handbook of Research Methods in Health Social Sciences. Singapore: Springer Singapore 201 9:269-83.

22 Silverman D. Doing qualitative research: A practical handbook, 3rd edn. Los Angeles: SAGE Publ 2011.

23 Charmaz K. Constructing grounded theory: A practical guide through qualitative analysis, 2nd edn. London: SAGE Publications 2006.

24 Schütze F. Biographieforschung und narratives Interview. Neue Praxis 1983;13(3):283-93.

25 Glaser B, Strauss AL. The discovery of grounded theory: Strategies for qualitative research, 4th edn. New Brunswick: Aldine 1967 // 2009.

26 Reichertz J. Gemeinsam interpretieren: Die Gruppeninterpretation als kommunikativer Prozess. Wiesbaden: Springer VS 2013.

27 Booth A, Hannes K, Harden A, et al. COREQ (Consolidated Criteria for Reporting Qualitative Studies). In: Moher D, Altman DG, Schulz KF, et al., eds. Guidelines for Reporting Health Research: A User's Manual. Oxford, UK: John Wiley \& Sons, Ltd 2014:214-26.

28 Enzenhofer E, Resch K. Übersetzungsprozesse und deren Qualitätssicherung in der qualitativen Sozialforschung. Forum: Qualitative Social Research $2011 ; 12(2)$.

29 Lefkowich M. When Women Study Men: Gendered Implications for Qualitative Research. International Journal of Qualitative Methods 201 9;1 8:1-9.

30 Catania G, Zanini M, Hayter M, et al. Lessons from Italian front-line nurses' experiences during the COVID-19 pandemic: a qualitative descriptive study. Journal of nursing management 2020. https://doi.org/10.1111/jonm.13194.

31 Zerbini G, Ebigbo A, Reicherts P, et al. Psychosocial burden of healthcare professionals in times of COVID-19 - a survey conducted at the University Hospital Augsburg. Ger Med Sci 2020;18.

32 Vindrola-Padros C, Andrews L, Dowrick A, et al. Perceptions and experiences of healthcare workers during the COVID-19 pandemic in the UK. BMJ Open 2020;10(11):e040503.

33 Fassier T, Azoulay E. Conflicts and communication gaps in the intensive care unit. Curr Opin Crit Care 2010;16(6):654-65.

34 Daugherty Biddison EL, Faden R, Gwon HS, et al. Too Many Patients...A Framework to Guide Statewide Allocation of Scarce Mechanical Ventilation During Disasters. Chest 2019;155(4):848-54.

35 Danjoux Meth N, Lawless B, Hawryluck L. Conflicts in the ICU: perspectives of administrators and clinicians. Intensive Care Med 2009;35(12):2068-77. 
medRxiv preprint doi: https://doi.org/10.1101/2021.01.29.21250626; this version posted March 19, 2021. The copyright holder for this preprint (which was not certified by peer review) is the author/funder, who has granted medRxiv a license to display the preprint in All rights reserved perpetuity.

\section{Supplementary information \\ COREQ Checklist - uploaded separately}

